10. KERAN, D. 1981. The incidence of man-caused and natural mortalities to raptors. Raptor Research 15:108-112.

11. KLIMKIEWICZ, M.K., and A.G. FUTCHER. 1989. Longevity of North American birds, supplement 1. Journal of Field Ornithology 60:469-494.

12. KREBS, CJ. 2001. Ecology. Benjamin Cummings, New York.

13. NERO, R.W. 1992. New Great Horned Owl longevity record. Blue Jay 50:91-92.

14. PAYEVSKY, V.A., and A.P. SHAPOVAL . 2000. Survival rates, life spans, and age structure of bird populations. Annual Reports of the Zoological Institute RAS. Zoological Institute, Russian Academy of Sciences, Universitetskaya nab. 1, St. Petersburg, 199034, Russia (http:// www.zin.ru/annrep/2000/17.html).
15. PITTAWAY, R. 1993. Subspecies of the Great Horned Owl. Ontario Birds 64-68.

16. ROWLEY, I., and E. RUSSELL. 1991. Demography of passerines in the temperate Southern Hemisphere. In: Perrins, C.M., J.-D. Lebreton, and Hirons, G.J.M. Bird Population Studies: Relevance to Conservation and Management. Pp. 22-44. Oxford University Press, Oxford.

17. TAVERNER, P.A. 1937. Birds of Canada. National Museum of Canada, Ottawa.

18. UNITED STATES GEOLOGICAL SURVEY. 2002. Bird Banding Laboratory web site: (http://www.pwrc.usgs.gov/bbl/ homepage/longvrec.htm).

19. ZEILIG, M. 1992. Park zoo forced to destroy oldest-known owl of species. Winnipeg Free Press, January 25, 1992.

\title{
THE SECOND ROSS'S GULL OF MY LIFE WAS A FIRST FOR SASKATCHEWAN
}

JAMES K. FINLEY, 10232 Summerset Place, Sidney, BC V8L 4X2

Dedicated to the memory of Wayne Harris, one of Saskatchewan's finest naturalists.

We drove down the road past the old Wise homestead, three biology students from the University of Saskatchewan, Wayne Harris, Wayne Renaud, and myself, and stopped at the "Wise Slough"* to study some shorebirds. It was 1971 or 72 . Renaud included some of our observations in his Birds of the Rosetown - Biggar District, though he didn't mention the flock of dowitchers. ${ }^{1}$ We argued over their identity so Harris and I collected a few for "study purposes", much to Renaud's chagrin.

Three decades after the dowitcher incident, on October 26th, 2002, I was driving down the same road past the Wise place with my brother-in-law, Brent Honeker, a local farmer, surveying the crops. It was a disastrous year, the fourth and most severe year of a deep drought; after a cold 


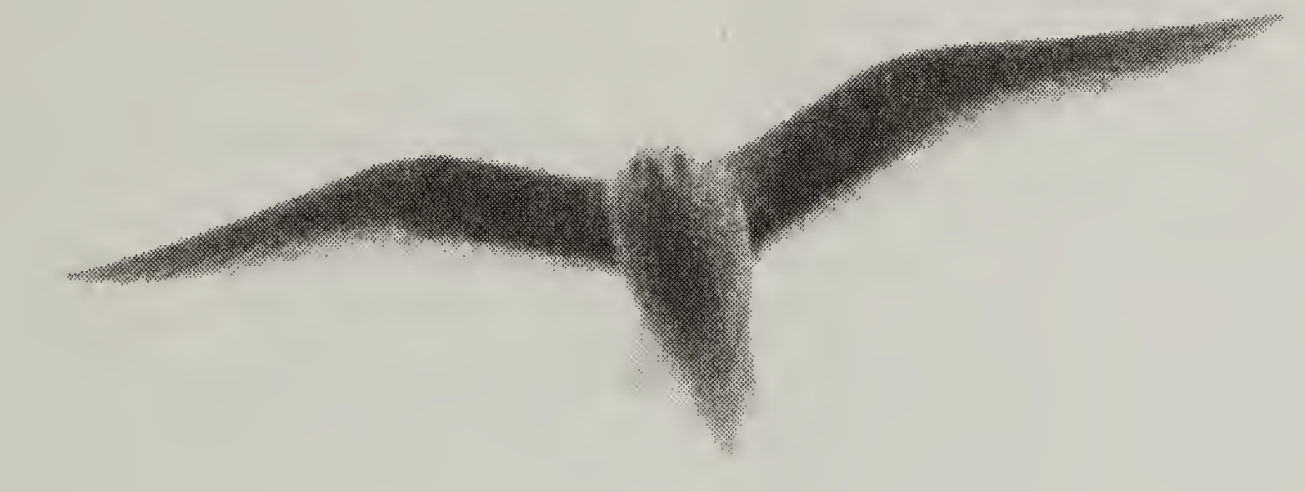

Figure 1. Ross's Gull in flight near the Wise place, October 26th, 2002. $52^{\circ} 09^{\prime} \mathrm{N}, 109^{\circ} 17^{\prime} \mathrm{W}$.

James K. Finley

windy spring and drifting soil, came intense heat, grasshoppers, sawflies, frost in early August, then a local cloudburst, and wet weather since. What little grain there was remained standing or in swaths and it appeared unlikely that it would be harvested. For the first time in my father's memory, during the spring, there was not a single slough remaining in a country that once boasted one of the highest densities of ducks and geese in the province. The municipality of Grass Lake was notable for having one of the lowest levels of precipitation in Palliser's Triangle during the growing season. Then came a freak deluge in mid-August that dumped six inches of rain overnight in a narrow swath along the glacial valley. Grass Lake Creek, which hasn't flowed in decades, backed up behind Zunti's road to a depth of ten or twelve feet, before drowning the grain-fields in the lake bottom. For the first time in many years, the lake and many surrounding sloughs had water; thousands of geese were flying out to feed on the unharvested crops. We saw several eagles, golden and bald, perched on granaries, waiting to pick up the wounded.

We passed the Wise Slough but it was dry; buffered by a strip of fescue prairie and crops, it had received no runoff. A quarter mile down the road, we slowed as four yellowlegs flushed from a roadside slough, and just as the far southwest corner of the slough was about to disappear behind the willows, I glimpsed a white bird swimming along the margin. Out of idle curiosity I asked my brother-in-law to back up. I studied the bird with binoculars for a while and was about to pass it off as an errant Bonaparte's Gull when it flushed with a tern-like flight and settled again. A Ross's Gull came to mind, and I harked back to an earlier time when I'd seen this species, and though I thought it extremely unlikely to see another, I left the comfort of the truck and crept around the willows, emerging close to where the bird was pecking at the surface. To my surprise, it proved to be an adult Ross's Gull with its distinctive wedgeshaped tail.

Pleased, I returned to the truck and informed my brother-in-law that he had a once-in-a-lifetime opportunity to see one of the rarest birds in North America, a pink gull from Siberia. Except it wasn't pink at this season, I explained, and was not quite as spectacular as the first (and only) other time I'd seen the species. I grabbed my camera and we returned to capture the record 
for posterity. Like many polar species unused to humans, the gull was tame, circling over our heads several times, curious over something other than a polar bear. I took one photograph but the light was poor and I doubted whether I'd captured the image. In jest, Brent suggested we could document it with a shotgun that he carried in the truck. In the old days, we might have done just that, I replied and mentioned the dowitcher incident, which brought on memories of Harris. We'd both sat with him in geography and biology classes in university.

"Harris" as we called him, to distinguish him from "Renaud", the other Saskatchewan ornithologist, was my lab partner in statistics. Hard to believe but we predated the electronic age; our calculations were made with huge mechanical calculators that required prodigious prodding before they spewed out our standard deviations. A good-hearted joker, he would drive me to distraction by punching in vast sums of nines, then dividing by vast sums of nines terminated with an eight. The machines would rattle on maddeningly until they seized up. Needless to say we barely scraped through stats.

Next morning, I returned, armed with faster film, but the slough was frozen over and the gull was gone. As the day was dull and cold, I returned to my childhood home and decided (after years of cajoling by my mother) to stay indoors and clean out my old dresser, a daunting task of deciding which marbles to keep, jackknives, rocks, bird bands, feathers, models, and a vast collection of nostalgic souvenirs. Ruthlessly I purged until I came to the bottom drawer full of old clothes. I was about to dump them in a garbage bag when I noticed an old grey sweater with an orange stain down its front. Remarkably, it was the same sweater I'd worn the first time I'd seen a Ross's Gull, and I was transported back in time.

It was on the seabird cliffs of Bylot Island, now a national park in the High
Arctic, and I was with an Eskimo family from Pond Inlet, collecting seabird eggs. It was July 2nd, 1979. I'd climbed part way up through a kittiwake colony, using an abraded rope that had been left from previous years, when my knees began to shake. As I hugged the cliff, trying to bolster my courage, a Ross's Gull passed close by, eyeing me curiously. It was a pink-hued adult in handsome breeding plumage, and though it did not imbue me with the courage to climb higher, it certainly impressed me. With some loss of face I retreated to the safety of the sea ice where the Ross's Gull was sitting with a gaggle of kittiwakes, while the daring Eskimos climbed higher to the murre colony.

Charlie (Kuvarqtaq) Enuaraq was a great joker and an intrepid egger. When he reached the murre ledges, much higher than I had climbed, he yelled that he had a gift for me, a beautiful murre egg, if I could catch it. By making a bib of my sweater, I gestured that I was willing. Murre eggs are beautiful hues of green and blue, finely splotched, sharply pointed so they don't roll off the edges, big as a chicken egg but heavier shelled, wonderfully aerodynamic. I took it squarely on the chin, leaving me stunned and reeling, bright orange, with yolk spattered down my sweater. Above the cacophony of seabirds, the cliff erupted with Charlie's laughter. Later, at our camp at Sunaruutit (Button Point), I told the hunters that I'd seen a very unusual bird, a pink gull from Russia. Charlie pointed at me, and his reply, in Inuktitut, nearly brought the tent down with laughter. "It looks like an orange bird to me".

It was the only sweater I had taken on the trip and I slept in it for several days while we camped along the ice edge hunting narwhals, eating muktuk and seabird eggs. "Looks like an orange bird to me" became a great joke along the ice edge, helping to melt the ice between our cultures. The stain never came out and it became something of a souvenir. 
The sighting of my first Ross's Gull, over two decades ago, was reported in an article on the birds of northern Baffin Island by Renaud et al. ${ }^{2}$ Renaud included me in the authorship, though that honour was never as close to my heart as that orange stain. With hesitation, I stuffed the sweater into the garbage bag.

What are the odds, I wondered, of finding the second Ross's Gull of my life near the Wise Place. I imagined Harris computing the standard deviation, dividing by that infernal eight, and laughing with glee. He would have enjoyed the irony and the host of factors that brought the little pink gull from Siberia in from the cold.

\section{Acknowledgements}

Thanks to Brent Honeker for backing up in time, and to Wayne Renaud and Gavin
Johnston for their comments and the fine memories. Anna Leighton kept me in line, as usual.

* The "Wise Slough", located beside the Wise family homestead, seven miles northeast of Luseland, was a wetland conservation project, initiated by my father, R.G. Finley, in the mid-sixties.

1. RENAUD, W. and D. RENAUD. 1975 . Birds of the Rosetown-Biggar District, Saskatchewan. Saskatchewan Natural History Society Special Publication No. 21. Regina.

2. RENAUD, W. G. JOHNSTON and K. J. FINLEY. 1981. The avifauna of Pond Inlet region, NWT. A spectacular mountain wilderness with a diverse arctic avifauna. American Birds 35 (2): 119-129,132-134.

\title{
URBAN-NESTING MERLINS AND COOPER'S HAWKS IN WEYBURN, SK
}

\author{
KELLY KOZIJ, 803 Coteau Avenue, Weyburn, SK S4H 0H1
}

\section{Merlins}

In the spring of 2002, I undertook to determine the numbers and nesting success of Merlins within the city limits of Weyburn, Saskatchewan. I had developed an interest in Merlins near Hendon, SK in the late 1980 s. Following my relocation to Weyburn in the fall of 1997, I observed Merlins in various areas of the city, which piqued my curiosity.

The majority of Merlin nests seemed to be concentrated within an area I describe as 'the older part of town'. This area is characterized by older buildings and more mature stands of trees as opposed to the more recently developed 'newer parts of town', with younger, shorter and thinner trees.

The trees in Weyburn are a mixture of deciduous and coniferous species planted by homeowners and the City Parks Department since the community was first formed at the end of the 19th century. An estimate of the ratio of the plantings on city-owned property is $25 \%$ coniferous and $75 \%$ deciduous trees (Claude Morin, City of Weyburn Parks Department, pers. comm.). No estimate is available for private property. 